\title{
AKTIVITAS ANTIOKSIDAN EKSTRAK DAUN KELOR (Moringa oleifera Lam.) DAN BUAH BIT (Beta vulgaris L.) SEBAGAI BAHAN TAMBAHAN MINUMAN SUPLEMEN
}

\author{
Tukiran $^{a^{*}}$, Mauren Gita Miranti ${ }^{b}$, Idah Dianawati $^{a}$, Fauzia Indah Sabila $^{a}$ \\ aJurusan Kimia, FMIPA, Universitas Negeri Surabaya, Jl. Ketintang Surabaya 60231

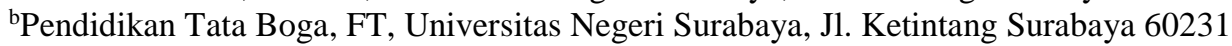 \\ *e-mail: tukiran@unesa.ac.id
}

Received 20 October 2020

Accepted 20 December 2020

\begin{abstract}
Abstrak
Minuman suplemen merupakan produk pelengkap kebutuhan zat gizi makanan yang mempunyai nilai gizi dan efek fisiologis dalam jumlah terkonsentrasi. Bahan tambahan dalam minuman suplemen dapat diperoleh dari tanaman yang memiliki aktivitas antioksidan. Daun kelor dan buah bit merupakan tanaman yang banyak dimanfaatkan sebagai antioksidan. Penelitian ini bertujuan untuk mengetahui aktivitas antioksidan ektstrak daun kelor dan buah bit sebagai bahan tambahan minuman suplemen. Ekstrak daun kelor dan buah bit diperoleh dari proses ekstraksi melalui metode maserasi dengan pelarut aqua steril pro injection. Uji aktivitas antioksidan dilakukan dengan metode 2,2-diphenyl-1-picrylhydrazyl (DPPH). Hasil penelitian menunjukkan ekstrak air daun kelor dan ekstrak air buah bit memiliki nilai IC 50 masing-masing sebesar 122,742 ppm (kategori sedang) dan 377,281 ppm (kategori lemah).
\end{abstract}

Kata kunci : 2,2-diphenyl-1-picrylhydrazyl, antioksidan, buah bit, daun kelor, $\mathrm{IC}_{50}$.

\begin{abstract}
Supplementary drink is a product that complements the nutritional needs of food that has a concentrated amount of nutritional value and physiological effect. Additional ingredients in supplement drinks can be obtained from plants that have antioxidant activity. Moringa leaves and beets are plants that are widely used as antioxidants. This study aims to determine the antioxidant activity of Moringa leaf and beetroot extracts as an additional ingredient in supplement drinks. Moringa leaf and beetroot extracts were obtained from the extraction process through the maceration with pro injection sterile aqua solvent. The antioxidant activity test was carried out using the 2,2-diphenyl-1-picrylhydrazyl (DPPH) method. The results showed that the water extracts of Moringa leaves and beetroot had IC50 values of $122.742 \mathrm{ppm}$ (moderate category) and 377.281 ppm (weak category), respectively.
\end{abstract}

Keywords : 2,2-diphenyl-1-picrylhydrazyl, Antioxidant, Beetroot, $\mathrm{IC}_{50}$, Moringa leaf.

\section{Pendahuluan}

Minuman suplemen merupakan minuman penambah energi yang termasuk ke dalam kategori suplemen makanan, merupakan produk pelengkap kebutuhan zat gizi makanan, mengandung satu atau lebih bahan berupa vitamin, mineral, asam amino atau bahan lain yang mempunyai nilai gizi dan/atau efek fisiologis dalam jumlah terkonsentrasi. Gizi makro dapat diperoleh dari protein yang berfungsi sebagai booster sistem imun tubuh. Gizi mikro banyak terdapat di sayur, buah, dan tanaman obat. Buah dan sayur banyak diolah menjadi minuman, yang selanjutnya dikenal dengan minuman multivitamin karena kandungan vitamin yang bermacam-macam. Minuman multivitamin dari minuman herbal dikonsumsi sebagai bagian dari diet yang dapat meningkatkan antioksidan dan meningkatkan kesehatan secara keseluruhan (Chandrasekara \& Shahidi, 2008). 
Antioksidan merupakan senyawa yang dapat memperlambat proses oksidasi dari radikal bebas. Radikal bebas adalah molekul yang memiliki satu atau lebih elektron yang tidak berpasangan pada orbital terluarnya, bersifat sangat reaktif dan tidak stabil. Radikal bebas akan bereaksi dengan atom atau molekul di sekitarnya untuk memperoleh pasangan elektron sebagai usaha untuk mencapai kestabilan. Mekanisme kerja senyawa antioksidan dalam menetralisir radikal bebas, yaitu dengan cara mendonorkan atom hidrogen atau proton pada senyawa radikal sehingga menghentikan reaksi berantai dari radikal bebas tersebut dan menjadikan radikal bebas lebih stabil (Lee et al., 2004). Radikal bebas dapat bersumber dari sisa hasil metabolisme tubuh atau dari luar tubuh seperti makanan, sinar UV, polutan dan asap rokok (Ratnayani et al., 2012).

Peningkatan jumlah radikal bebas dalam tubuh akan menyebabkan stress oksidatif yang mampu merusak struktur sel, jaringan lemak, protein sistem kekebalan, dan DNA (Salamah \& Widyasari, 2015; Simanjuntak, 2012). Stress oksidatif dapat memicu penyakit degeneratif, seperti kanker, diabetes, peradangan dan kardiovaskuler (Wijeratne. 2005; Sjahrir, 2006; Stocker \& Keany, 2004). Salah satu penyebab utama penyakit degeneratif adalah ketidaksetimbangan antara jumlah radikal bebas dengan antioksidan yang tersedia dalam tubuh. Kebutuhan antioksidan dalam tubuh dapat terpenuhi melalui konsumsi makanan yang mengandung antioksidan (Atun, 2006). Berbagai bahan alam asli Indonesia banyak mengandung antioksidan dengan berbagai bahan aktifnya, antara lain vitamin $\mathrm{C}, \mathrm{E}$, pro vitamin $\mathrm{A}$, organosulfur, $\alpha$-tocopherol, senyawa fenolik atau polifenolik yang dapat berupa golongan flavonoid, kumarin, dan lainnya (Werdhasari, 2014).

Salah satu tanaman yang banyak dimanfaatkan sebagai antioksidan adalah tumbuhan kelor, terutama pada bagian daunnya. Daun kelor juga bermanfaat dalam penurun tekanan darah tinggi dan obat diabetes (Giridhari et al., 2011) dan antibakteri (Bukar \& Oyeyi, 2011). Daun kelor mengandung mineral, asam amino esensial, antioksidan seperti vitamin C, vitamin $\mathrm{E}$, dan kaya akan metabolit sekunder lainnya. Hasil uji fitokimia daun kelor menunjukkan adanya tanin, alkaloid, flavonoid, saponin antraquinon, steroid dan triterpenoid yang berperan sebagai antioksidan (Kasolo et al., 2010).

Buah bit merupakan tanaman dari famili Amarathaceae yang berbentuk umbiumbian. Buah bit mengandung vitamin dan mineral seperti vitamin $\mathrm{B}$, vitamin $\mathrm{C}$, kalsium, fosfor, dan besi (Wirakususmah, 2007). Buah bit juga mengandung pigmen betasianin, yaitu pigmen berwarna merah keunguan yang dimanfaatkan sebagai pewarna alami dalam pembuatan produk pangan. Betasianin merupakan senyawa yang termasuk kelompok flavonoid dan bersifat polar karena mengikat gula dan pigmen bernitrogen dan diketahui memiliki efek antioksidan (Mastuti et al., 2010). Hal tersebut yang melatarbelakangi penambahan ekstrak dari daun kelor dan buah bit untuk meningkatkan kandungan antioksidan dalam minuman suplemen.

Metode pengukuran aktivitas antioksidan yang sering digunakan adalah metode uji menggunakan radikal bebas DPPH. DPPH merupakan radikal bebas yang dapat bereaksi dengan senyawa yang dapat mendonorkan atom hidrogen dan berguna untuk pengujian aktivitas antioksidan komponen tertentu dikarenakan adanya elektron yang tidak berpasangan sehingga DPPH memberikan serapan kuat pada 517 nm (Abbas et al., 2009).

Penelitian ini bertujuan untuk mengetahui aktivitas antioksidan dari ekstrak daun kelor dan buah bit secara kuantitatif dan diharapkan dapat meningkatkan nilai guna dari daun kelor dan buah bit dengan memanfatakannya sebagai bahan tambahan dalam pembuatan minuman suplemen.

\section{Metode Penelitian Bahan}

Bahan-bahan yang digunakan dalam 
penelitian ini adalah daun kelor kering, buah bit kering, kertas saring, aluminium foil, water steril pro-injection, metanol p.a, metanol teknis, aquades, dan DPPH.

\section{Alat}

Alat yang digunakan pada penelitian ini adalah tabung reaksi, rak tabung reaksi, botol vial, gelas ukur, gelas kimia, labu ukur, pipet tetes, corong kaca, spatula, blender, mikropipet, neraca analitik, tabung sentrifuge, corong Buchner, pompa vakum, sentrifuge, vacuum rotary evaporator, dan spektrofotometer UV-VIS (Shimadzu UV1800)

\section{Tahap Preparasi Sampel}

Sampel kering yang berupa daun kelor dan buah bit kering dihaluskan dengan blender hingga menjadi sampel serbuk, lalu ditimbang sebanyak 100 gram. Serbuk sampel dimaserasi dengan pelarut aqua steril pro-injection dengan metode maserasi selama 4 jam dalam toples kaca. Serbuk sampel sebanyak $100 \mathrm{~g}$ direndam dalam 250 $\mathrm{mL}$ pelarut atau volume pelarut berada $1 \mathrm{~cm}$ di atas sampel. Hasil maserasi disaring secara vakum menggunakan corong Buchner dan pompa vakum sehingga diperoleh filtrat dan residu maserat. Filtrat yang diperoleh diuapkan dengan vacuum rotary evaporator dengan suhu $\pm 40{ }^{\circ} \mathrm{C}$ pada tekanan 13 mbar dan rotasi $60 \mathrm{rpm}$ sehingga didapatkan ekstrak kental air daun kelor dan buah bit. Setelah itu masing-masing ekstrak kental ditimbang untuk menghitung persen rendeman dengan persamaan:

$$
\begin{aligned}
& \% \text { Rendemen } \\
& =\frac{\text { Berat Ekstrak Pekat }}{\text { Berat Serbuk daun kelor }} \times 100 \%
\end{aligned}
$$

\section{Tahap Uji Aktivitas Antioksidan}

Uji aktivitas antioksidan ekstrak air daun kelor dan buah bit dilakukan dengan metode DPPH. Tahapan yang dilakukan sebagai berikut: membuat larutan induk dari $10 \mathrm{mg}$ ekstrak kental dilarutkan dalam metanol p.a dalam labu ukur $10 \mathrm{~mL}$. Membuat larutan uji dengan konsentrasi 10, 25, 50, 75 dan 100 ppm dari larutan induk. Masing-masing variasi larutan uji tersebut dimasukkan dalam vial berwarna gelap dan ditambahkan dengan metanol p.a sampai 2 mL, kemudian ditambahkan $2 \mathrm{~mL}$ larutan DPPH 0,004\%. Larutan uji diinkubasi selama 30 menit pada suhu ruang di ruangan gelap. Kemudian diukur absorbansinya dengan spektrofotometer UV-Vis pada $\lambda$ maks $517 \mathrm{~nm}$. Perlakuan yang sama dilakukan terhadap kontrol dimana larutan sampel diganti dengan metanol p.a. Data absorbansi yang diperoleh dipergunakan untuk menghitung persen inhibisi (\%I) dengan menggunakan persamaan:

$$
\% I=\frac{A_{b}+A_{s}}{A_{b}} \times 100 \%
$$

Selanjutnya antara \%I dan konsentrasi sampel diplotkan untuk memperoleh persamaan regresi yang berfungsi mencari nilai $\mathrm{IC}_{50}$ dari ekstrak daun kelor dan buah bit.

\section{Hasil dan Pembahasan}

Kelor merupakan salah satu tanaman yang kaya akan nutrisi berupa vitamin, mineral, asam amino dan senyawa fitokimia yang dapat berperan sebagai antioksidan salah satunya pada bagian daun. Selain itu, buah bit merupakan tanaman yang memiliki betasianin berwarna merah keunguan yang berfungsi sebagai pewarna alami dan memiliki aktivitas antioksidan yang cukup tinggi. Dalam penelitian ini digunakan daun kelor dan buah bit kering dengan tujuan daya simpan sampel dapat lebih lama, mengurangi kontaminasi dari jamur dan menghentikan proses enzimatis pada sampel yang dapat menguraikan lebih lanjut kandungan zat aktif (Agoes, 2007). Sampel daun kelor dihaluskan dengan tujuan untuk memperkecil ukuran dan luas permukaannya semakin besar, maka interaksi dengan zat cairan ekstraksi akan semakin besar pula, sehingga proses ektraksi akan semakin efektif.

Ekstrak daun kelor dan buah bit diperoleh dengan menggunakan metode maserasi. Metode maserasi merupakan proses difusi pelarut ke dalam dinding sel tumbuhan yang mengandung senyawa aktif. Senyawa aktif akan larut karena perbedaan 
konsentrasi antara larutan senyawa aktif dalam dan di luar sel. Metode maserasi cocok digunakan untuk mengekstraksi komponen kimia yang kurang tahan terhadap panas termasuk zat aktif antioksidan.

Pelarut yang digunakan dalam ekstraksi adalah pelarut aqua steril pro-injection. Bahan ini berupa air untuk injeksi yang disterilkan dan dikemas dengan cara yang sesuai, tidak mengandung bahan antimikroba atau bahan tambahan lainnya. Pelarut ini dapat dibuat dari penyulingan atau penyaringan untuk menghilangkan mikroorganisme atau zat asing yang tidak diinginkan. Pelarut ini dapat dipastikan merupakan air yang steril dibandingkan dengan aquadest biasa sehingga adanya kontaminan lebih kecil. Pelarut air merupakan pelarut yang bersifat polar dan dapat melarutkan beberapa kandungan metabolit sekunder (Tiwari et al., 2011). Pelarut air merupakan pelarut yang sangat baik untuk senyawa ion. Gugus - $\mathrm{OH}$ yang bersifat polar dan memberikan suatu dipol yang perlu untuk mengsolvasi kation dan anion keduanya (Sa'adah \& Nurhasanawati, 2015). Penggunaan pelarut ini dalam proses ekstraksi tidak akan berbahaya, jika hasil ekstraksi diaplikasikan atau ditambahkan dalam produk makanan atau minuman.

Hasil dari proses maserasi diperoleh ekstrak cair yang selanjutnya diuapkan dengan vacuum rotary evaporator pada suhu $\pm 40{ }^{\circ} \mathrm{C}$ dan tekanan 13 mbar dengan kecepatan rotasi $60 \mathrm{rpm}$, sehingga diperoleh ekstrak kental. Pompa vakum pada penguapan ini akan membantu untuk menurunkan tekanan pada permukaan sehingga pelarut akan menguap di bawah titik didih normalnya dan dapat mengurangi terjadinya penguraian senyawa yang terdapat dalam ekstrak akibat pemanasan yang berlebih. Hasil ekstraksi yang diperoleh berupa ekstrak kental daun kelor yang berwarna kuning kehijauan sebanyak 24,233 gram dan ektrak kental bit berwarna merah keunguan sebanyak 35,407 gram. Ekstrak kental berasal dari 100 gram sampel kering sehingga diperoleh persen rendemen sebesar $24,233 \%$ untuk ekstrak daun kelor dan $35,407 \%$ untuk ekstrak buah bit.
Ekstrak air daun kelor dan buah bit yang diperoleh, masing-masing diuji aktivitas antioksidannya dengan metode pengukuran serapan radikal DPPH. DPPH merupakan senyawa radikal bebas yang stabil. Prinsip dari uji antioksidan dengan metode DPPH adalah penangkapan hidrogen dari senyawa antioksidan oleh radikal bebas DPPH yang diketahui dari perubahan warna DPPH dari ungu pekat menjadi kuning. Perubahan warna tersebut dijadikan patokan pengukuran intensitas warna dengan spektrofotometer UV-Vis pada panjang gelombang maks $517 \mathrm{~nm}$. Dalam uji aktivitas antioksidan digunakan 5 variasi konsentrasi, yaitu 10, 25, 50, 75 dan 100 ppm. Hasil uji aktivitas antioksidan ekstrak air daun kelor dan buah bit disajikan dalam tabel 1 dan 2.

Tabel 1. Hasil Uji Antioksidan Ekstrak Air Daun Kelor

\begin{tabular}{llll}
\hline $\begin{array}{c}\text { Konsentra } \\
\text { si }(\mathbf{p p m})\end{array}$ & \multicolumn{2}{c}{$\begin{array}{c}\text { Absorbansi } \\
\text { (A) }\end{array}$} & \multirow{2}{*}{ \% I } \\
\cline { 2 - 3 } & Blanko & Sampel & \\
\hline $\mathbf{1 0}$ & & 0.6578 & 7.2345 \\
$\mathbf{2 5}$ & \multirow{2091}{*}{0.6068} & 14.4267 \\
$\mathbf{5 0}$ & & 0.5465 & 22.9305 \\
$\mathbf{7 5}$ & & 0.4696 & 33.7752 \\
$\mathbf{1 0 0}$ & & 0.4225 & 40.4174 \\
\hline
\end{tabular}

Tabel 2. Hasil Uji Antioksidan Ekstrak Air buah Bit

\begin{tabular}{lcll}
\hline $\begin{array}{l}\text { Konsen- } \\
\text { trasi }\end{array}$ & \multicolumn{2}{c}{ Absorbansi } & \multirow{2}{*}{ \% I } \\
\cline { 3 - 3 }$(\mathbf{p p m})$ & Blanko & Sampel & \\
\hline $\mathbf{1 0}$ & & 0.7014 & 1.0859 \\
$\mathbf{2 5}$ & & 0.6914 & 2.4961 \\
$\mathbf{5 0}$ & $\mathbf{0 . 7 0 9 1}$ & 0.6653 & 6.1768 \\
$\mathbf{7 5}$ & & 0.6342 & 10.56 \\
$\mathbf{1 0 0}$ & & 0.6213 & 12.3819 \\
\hline
\end{tabular}

Berdasarkan tabel 1 dan 2. diketahui semakin meningkatnya konsentrasi ekstrak air daun kelor, maka semakin kecil nilai absorbansi yang diporeleh dan berbanding terbalik dengan nilai inhibisi yang semakin besar. Persen inhibisi menunjukkan kemampuan ekstrak dalam menghambat aktivitas radikal bebas yang berhubungan 
dengan konsentrasi ekstrak. Persen inhibisi yang diperoleh diplotkan sebagai fungsi $\mathrm{x}$ dan y ke dalam persamaan regresi linier untuk mengetahui nilai $\mathrm{IC}_{50}$, yaitu konsentrasi larutan sampel yang dibutuhkan untuk menghambat $50 \%$ radikal bebas DPPH. Semakin kecil nilai $\mathrm{IC}_{50}$ yang diperoleh, maka semakin tinggi aktivitas antioksidannya (Zuhra, (2008). Kurva hasil uji antioksidan ekstrak air daun kelor dan buah bit disajikan pada Gambar 1 dan 2 .

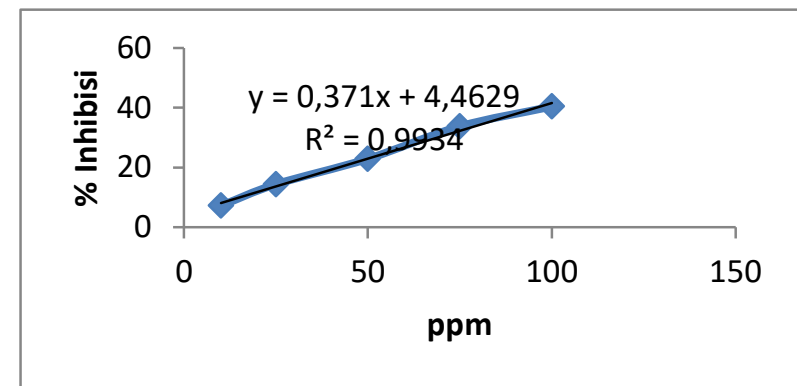

Gambar 1. Kurva Hasil Uji Antioksidan Ekstrak Air Daun Kelor

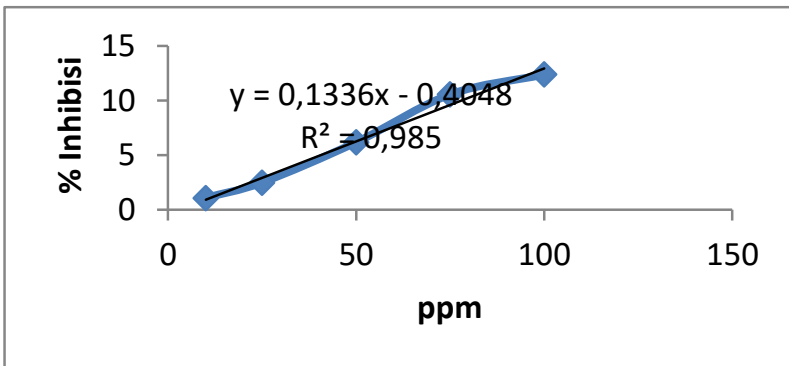

Gambar 2. Kurva Hasil Uji Antioksidan Ekstrak Air Buah Bit

Berdasarkan hasil analisis regresi linier hubungan antara konsentrasi ekstrak dengan persen inhibisi diperoleh persamaan regresi $\mathrm{y}=0.371 \mathrm{x}+4.4629$ untuk ekstrak air daun kelor dan $\mathrm{y}=0.1336 \mathrm{x}-0.4048$ untuk ekstrak air buah bit. Dari persamaan tersebut dapat ditentukan nilai $\mathrm{IC}_{50}$ dari ekstrak air daun kelor dan daun bit yaitu sebesar 122,742 ppm dan $377.281 \mathrm{ppm}$. Hasil tersebut dikategorikan berdasarkan tabel 3, tingkat kekuatan antioksidan ekstrak air daun kelor tergolong sebagai antioksidan golongan sedang. Sedangkan ekstrak air buah bit tergolong sebagai antioksidan golongan lemah. Nilai IC $_{50}$ ekstrak air daun kelor yang diperoleh lebih kecil dibandingkan dengan hasil penelitian Kiswododo dan Maslahat
(2011) yang mengatakan nilai IC $_{50}$ ekstrak air daun kelor sebesar 189,21 ppm. Nilai $\mathrm{IC}_{50}$ ekstrak air buah bit yang diperoleh lebih besar dibandingkan dengan hasil penelitian Novatama et al. (2016) yaitu 79,73 ppm. Perbedaan tersebut dapat dipengaruhi oleh beberapa faktor diantaranya faktor geografis, genetic, sumber benih tanaman, kondisi iklim dan kesuburan tanah yang dapat mempengaruhi kandungan dari tanaman (Giridhari et al., 2011).

Tabel 3. Tingkat Kekuatan Antioksidan dengan Metode DPPH (Syarif et al., 2008).

\begin{tabular}{ll}
\hline Intensitas & Nilai IC50 \\
Antioksidan & \\
\hline Sangat kuat & $<50 \mathrm{ppm}$ \\
Kuat & $50-100 \mathrm{ppm}$ \\
Sedang & $100-250 \mathrm{ppm}$ \\
Lemah & $250-500 \mathrm{ppm}$ \\
\hline
\end{tabular}

Berdasarkan nilai $\mathrm{IC}_{50}$, ekstrak air daun kelor dan buah bit berpotensi sebagai antioksidan. Kandungan senyawa pada daun kelor dan buah bit berperan sebagai senyawa antioksidan. Syarif et al. (2008), mengatakan bahwa senyawa antioksidan alami yang dimiliki tumbuhan di antaranya adalah senyawa fenolik atau polifenol, termasuk pula flavonoid (Blois, 1958). Daun kelor diketahui mengandung beberapa flavonoid antara lain kaemferol, kuarsetin, rhamnetin, kuarsetin, dan proantosianidin (Saleem, 1995). Selain itu, buah bit memiliki kandungan senyawa flavonoid, betasianin, betalain, asam askorbat dan karetinoid yang berperan sebagai senyawa antioksidan (Ananda, 2008). Reaksi antara senyawa antioksidan dengan radikal bebas DPPH dapat disajikan dalam Gambar 3.

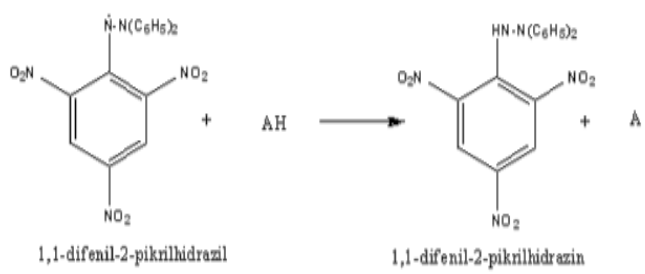

Gambar 3. Reaksi Uji Antioksidan (Kiswandono \& Maslahat, 2011). 
Senyawa flavonoid memiliki efek antioksidan disebabkan adanya penangkapan radikal bebas DPPH, dimana terjadi reduksi senyawa DPPH menjadi senyawa non radikal. Dalam hal ini, flavonoid berperan dalam mendonorkan proton hidrogen atau elektronnya dari gugus hidroksil flavonoid kepada radikal bebas untuk mengstabilkan senyawa radikal. Oleh karena itu, semakin tinggi kandungan flavonoid dalam ekstrak air daun kelor dan buah bit, maka akan semakin tinggi aktivitas antioksidannya (Amic et al., 2003).

\section{Kesimpulan}

Berdasarkan hasil penelitian yang telah dilakukan dapat disimpulkan bahwa ekstrak air daun kelor yang diuji aktivitas antioksidannya dengan metode DPPH memiliki nilai $\mathrm{IC}_{50}$ sebesar $122,742 \mathrm{ppm}$ yang berpotensi sebagai antioksidan alami dan tergolong sebagai antioksidan katagori sedang. Ekstrak air buah bit memiliki aktivitas antioksidan dengan nilai $\mathrm{IC}_{50}$ sebesar 377,281 ppm dan tergolong antioksidan lemah.

\section{Ucapan Terima Kasih}

Terimakasih disampaikan kepada DRPM Kemenristek/BRIN yang mendanai kegiatan penelitian ini melalui kontrak penelitian DRPM multitahun 2020 s.d 2022 dengan no:

B/11643/UN38.9/LK.04.00/2020, tertanggal 29 Maret 2020.

\section{Daftar Pustaka}

Abbas, A. Dehpour, M. A. Ebrahimzadeh, S. F. Nabavi and S. M. Nabavi, 2009. Antioxidant activity of methanol extract of Ferula assafoetida and its essential oil composition, Grasas y Aceites, 60(4), 405-412.

Agoes, G. 2007. Teknologi Bahan Alam. Institut Teknologi Bandung.

Amic, D., Davidovic-Amic, D., Beslo, D. and Trinajstic, N. 2003. Structureradical scavenging activity relationship of flavonoids. Croatica Chemica Acta, 76(1), 55-61.

Ananda, L. 2008. Karakteristik fisikokimia serbuk bit merah (Beta vulgaris L.), Pertanian Universitas Katolik Soegijapranata, Semarang.

Atun, S. 2006. Hubungan struktur dan aktivitas antioksidan beberapa senyawa resveratrol dan turunannya, Universitas Negeri Yogyakarta, Yogyakarta.

Blois, M. S., 1958. Antioxidant determinations by the use of stable free radical. Nature, 81(4617), 1199-1200.

Bukar, A., \& Oyeyi, T. I., 2011. Antimicrobial profile of Moringa oleifera Lam. extract against some food-borne microorganisms. Bayero $J$. Pure Appl. Sci., 3(1), 43-48.

Chandrasekara, A. \& Shahidi, F. 2008. Herbal beverages: bioactive compounds and their role in disease risk reduction A review. J Tradit Complement Med., 8(4), 451-458.

Giridhari, V. V. A., D. Malathi \& K. Geetha, 2011. Anti-diabetic properties of drumstick (Moringa oleifera) leaf tablets. Int J Health Nutr., 2(1), 1-5.

Kasolo, J. N., Bimeya, G. S., Ojok, L., Ochieng, J. \& Okwal-okeng, J. W. 2010. Phytochemicals and uses of Moringa oleifera leaves in Ugandan Rural Communities Josephine. J. Med. Plants Res., 6(2), 753-757.

Kiswandono, A. A., \& Maslahat, M., 2011. Uji antioksidan ekstrak heksana, etil asetat, etanol, metanol $80 \%$ dan air daun kelor (Moringa oleifera Lamk). Jurnal Sains Natural Universitas Nusa Bangsa, 1(1), 39-44.

Lee, J., Koo, N., \& Min, D. B., 2004. Reactive oxygen species, aging, and antioxidative nutreceuticals, Compr. Rev. Food Sci. Food Saf., 1(3), 21-33.

Mastuti, C. Yizhong, \& Harold, C. 2010. Identifikasi pigmen betasianin pada beberapa jenis Inflorescence celosia, $J$. Biol. UGM, 66(6), 664-672.

Novatama, S. M., Kusomo, E. \& Supartono, 2016. Identifikasi betasianin dan uji antioksidan ekstrak buah bit merah (Beta vulgaris L.), Indo. J. Chem. Sci., 5(3), 217-220.

Ratnayani, K. A. A., Laksmiwati, I. A. M., 
\& Septian, N. P. I. 2012. Kadar total senyawa fenolat pada madu randu dan madu kelengkeng serta uji aktivitas antiradikal bebas dengan Metode DPPH (difenilpikril hidrazil). J. Kim., 6(2), 163-168.

Salamah, N., \& Widyasari, E., 2015. Aktivitas antioksidan ekstrak metanol daun kelengkeng (Euphoria longan L.) dengan metode penangkapan radikal 2,2'-difenil-1-pikrilhidrazil.

Pharmaciana, 5(1), 25-34.

Saleem, R. 1995. Studies in the chemical constituents of Moringa oleifera Lamk and preparation of the potential biologically significant derivatives of 8hydroxyquinoline, Thesis, Tidak Dipublikasikan.

Simanjuntak, K., 2012. Peran antioksidan flavonoid dalam meningkatkan kesehatan. Bina Widya, 23(3), 135-140.

Sjahrir, H. 2006. Diabetic neuropathy: the pathoneubiology \& treatment update. USU Press, Medan.

Stocker, R. \& Keany, J. F., 2004. Role of oxidative modifications in atherosclerosis. Physiol. Rev., 1(84), 1381-1478.

Syarif, R. A., Aktsar, R. Oskiana A. \& Malik, A., 2008. Identifikasi golongan senyawa antioksidan dengan metode perendaman radikal bebas DPPH ekstrak etanol daun Cordia myxa L., Fitofarmaka Indonesia, 2(1), 83-89.

Tiwari, P., K. Mandeep, and K. Harleen, 2011. Phytochemical screening and extraction: a review, Int. Pharm. Sci., 1(1), 2011.

Werdhasari, A. 2014. Peran antioksidan bagi kesehatan. J. Biotek Medisiana Indones., 3(2), 59-68.

Wijeratne, S. S. K., Cuppett, S. L. \& Schlegel, V., 2005. Hydrogen peroxide induced oxidative stress damage and antioxidant enzyme response in cacohuman colon cells. J. Agric. Food Chem., 1(53), 8768-8774.

Wirakususmah, E., 2007. Cantik awet muda dengan buah sayur dan herbal. Surabaya: Penebar Swadaya.

Zuhra, 2008. Aktivitas antioksidan senyawa flavonoid dari daun katuk (Sauropus androganus (L) Merr.), J. Biol. Sumat., 3(1), 2008. 